\title{
Potential Impact of Two Aphthona spp. on a Native, Nontarget Euphorbia Species
}

\author{
Stefanie D. Wacker ${ }^{1}$ and Jack L. Butler ${ }^{2}$ \\ Authors are ${ }^{1}$ Research Associate, Department of Forest, Rangeland, and Watershed Stewardship, \\ Colorado State University, Fort Collins, CO 80523-1472; and ${ }^{2}$ Research Ecologist, USDA Forest Service, \\ Rocky Mountain Research Station, Rapid City, SD 57702.
}

\begin{abstract}
Flea beetles (Aphthona spp.) are biological control agents introduced from Eurasia to reduce the cover and density of leafy spurge (Euphorbia esula L.). The potential for the introduced beetles to use alternate hosts for feeding and development in North America is slight; however, it is possible. Species at highest risk are native species closely related, ecologically and taxonomically, to leafy spurge. A native spurge, Euphorbia brachycera Engelm. is consubgeneric and sympatric with leafy spurge throughout the northern Great Plains of the United States, and was not included in prerelease host-specificity testing for Aphthona nigriscutis or Aphthona lacertosa. The objective of this study was to evaluate the actual and potential ecological overlap among leafy spurge, flea beetles, and E. brachycera. Wide-ranging and intensive field surveys indicate that E. brachycera is found well within the range of leafy spurge and flea beetles. E. brachycera occurs infrequently, in low densities, in areas with a high percentage of bare ground, and with a root system dissimilar to leafy spurge. Flea beetles released directly into populations of E. brachycera failed to persist beyond a single field season and plants showed no evidence of feeding by beetles. Our results suggest that the potential for flea beetles to host-shift is low due to differences in growth habit and root morphology between E. brachycera and leafy spurge.
\end{abstract}

\begin{abstract}
Resumen
Los escarabajos "Pulga" (Aphthona spp.) son agentes de control biológico introducidos de Eurasia para reducir la cobertura y densidad de "Leafy spurge" (Euphorbia esula L.). El potencial de los escarabajos introducidos para usar hospederos alternativos para alimentarse y desarrollarse en Norteamérica es bajo, sin embargo, es posible. Las especies con mayor riesgo son especies nativas cercanamente relacionadas ecológica y taxónomicamente al "Leafy spurge." Un "Spurge" nativo Euphorbia brachycera Engelm. es consubgenerico y simpatrico con el "Leafy spurge" a través de las Grandes Planicies de Estados Unidos de América y no fue incluido en las pre-liberaciones de prueba para determinar las especificidad de los hospederos del Aphthona nigriscutis o Aphthona lacertosa. El objetivo de este estudio fue evaluar el traslape ecológico actual y potencial entre el "Leafy spurge," los escarabajos "Pulga" y E. brachycera. Muestreos de campo amplios e intensivos indican que E. robusta se encuentra dentro del rango del "Leafy spurge" y de los escarabajos "Pulga." E. brachycera ocurre infrecuentemente, en bajas densidades, en áreas con alto porcentaje de suelo desnudo y con un sistema radical diferente al del "Leafy spurge." Los escarabajo "Pulga" liberados directamente en poblaciones de E. brachycera fracasaron en persistir mas allá de una sola estación y las no plantas mostraron evidencia de que hayan sido consumidas por los escarabajos. Nuestros resultados sugieren que el potencial de los escarabajos de ocupar otros hospederos es bajo debido a diferencias en el hábito de crecimiento y morfología de la raíz entre E. brachycera y "Leafy spurge."
\end{abstract}

Key Words: ecological separation, ecological risk, leafy spurge

\section{INTRODUCTION}

In an effort to control invasive plants such as leafy spurge (Euphorbia esula L.) and Canada thistle (Cirsium arvense [L.] Scop.), many integrated pest management plans include the use of biological control agents in conjunction with herbicides. While biological control is often considered safer (Van Driesche

Research was funded by USDA-ARS TEAM Leafy Spurge and USDA Forest Service Rocky Mountain Research Station.

At the time of research S.D.W. was Graduate Research Assistant, Department of Biology and Microbiology, South Dakota State University, Brookings, SD.

Correspondence: Stefanie D. Wacker, USDA Forest Service, Rocky Mountain Research Station, 1730 Samco Rd, Rapid City, SD 57702. Email: swacker@fs.fed.us

Manuscript received 1 December 2005; manuscript accepted 26 March 2006.
1994) than chemical control, it is not without ecological risk. Potential risks specific to the biological control of weeds include food-web alterations (Pearson and Callaway 2003) and host-shifting of biocontrol agents onto cultivated and/or native plants (Pemberton 1984). Organisms most threatened by host-shifting of biocontrol agents are native plants most closely related ecologically and taxonomically to the target species (Pemberton 2000). Additionally, as the target population declines, the potential impact on nontarget species being used as forage and as a developmental host increases.

Use of nontarget species by biocontrol insects has been documented for several native plants. Louda and O'Brien (2002) reported that the seed-feeding weevil Larinus planus Fabricius, established in the United States and Canada for the control of Canada thistle, often foraged on the native Tracy's thistle, Cirsium undulatum (Nutt.) Spreng. var. tracyi (Rydb.) 
Table 1. Site name, site abbreviations, date of vegetation survey, topographic characteristics, and location for each study site.

\begin{tabular}{|c|c|c|c|c|c|c|c|}
\hline Site & Site abbrev. & Date of survey (2002) & Slope & Elevation (m) & Aspect & Latitude & Longitude \\
\hline Wind Cave 1 & WICA1 & 17 June & $14^{\circ}$ & 1170 & south & $43^{\circ} 35^{\prime} 29.5^{\prime \prime}$ & $103^{\circ} 23^{\prime} 29.2^{\prime \prime}$ \\
\hline Wind Cave 2 & WICA2 & 29 June & $8^{\circ}$ & 1164 & southeast & $43^{\circ} 35^{\prime} 14.3^{\prime \prime}$ & $103^{\circ} 23^{\prime} 35.4^{\prime \prime}$ \\
\hline Lander 1 & LAN1 & 21 June & $16^{\circ}$ & 1841 & northeast & $42^{\circ} 48^{\prime} 06.1^{\prime \prime}$ & $108^{\circ} 47^{\prime} 43.6^{\prime \prime}$ \\
\hline Lander 2 & LAN2 & 23 June & $20^{\circ}$ & 1646 & west & $42^{\circ} 50^{\prime} 11.9^{\prime \prime}$ & $108^{\circ} 34^{\prime} 02.1^{\prime \prime}$ \\
\hline Lander 3 & LAN3 & 24 June & $2^{\circ}$ & 2060 & southeast & $42^{\circ} 36^{\prime} 58.1^{\prime \prime}$ & $108^{\circ} 26^{\prime} 43.9^{\prime \prime}$ \\
\hline Lander 4 & LAN4 & 25 June & $9^{\circ}$ & 2054 & south & $42^{\circ} 37^{\prime} 00.4^{\prime \prime}$ & $108^{\circ} 26^{\prime} 56.8^{\prime \prime}$ \\
\hline Black Hills 1 & $\mathrm{BH} 1$ & 12 July & $2^{\circ}$ & 1408 & southeast & $43^{\circ} 39^{\prime} 21.5^{\prime \prime}$ & $104^{\circ} 01^{\prime} 41.8^{\prime \prime}$ \\
\hline Black Hills 2 & $\mathrm{BH} 2$ & 13 July & $5^{\circ}$ & 1408 & south/southwest & $43^{\circ} 39^{\prime} 21.9^{\prime \prime}$ & $104^{\circ} 01^{\prime} 44.6^{\prime \prime}$ \\
\hline
\end{tabular}

Welsh. Nontarget feeding by a biocontrol agent was discovered in several populations of cacti (Opuntia spp.) in Florida, some of which are rare and endangered (Stiling and Moon 2001). While the cactus-feeding moth, Cactoblastis cactorum Bergroth, was not released in the conterminous United States, it has traveled to Florida from the Caribbean naturally or on cacti imported for the horticultural market (Pemberton 1995).

Prior to intentional release, potential biocontrol agents undergo rigorous host-specificity testing including adult feeding preferences and oviposition (Gassmann et al. 1996). Despite these laboratory tests, there have been cases in which an agent has been identified as host-specific in the laboratory (Zwölfer and Harris 1984) but field evidence demonstrated otherwise (Turner et al. 1987; Louda et al. 1997; Louda et al. 2003). However, not all host specificity tests can accurately predict ecological interactions once the agent has been introduced into a new environment (Pearson and Callaway 2003). Furthermore, few biocontrol programs include post-release field tests (Simberloff and Stiling 1996). Specifically, no published studies involving leafy spurge have been found that simultaneously addressed the ecological relationships among biocontrol agents, the intended target, and potential nontarget species. Dissimilar ecological relationships among principal species may play a subtle but important role in reducing the potential nontarget impacts.

Leafy spurge is an exotic, invasive weed that infests over 5 million acres in 35 states in the western and northern United States and the Canadian prairie provinces (TEAM Leafy Spurge, http://www.team.ars.usda.gov). Heavy and widespread infestations have caused damage to a variety of ecosystems, cost millions of dollars due to lost productivity, and increased ecological damage from the heavy use of herbicides (Bangsund and Leistritz 1991). Biocontrol programs were developed and incorporated into integrated pest management strategies for leafy spurge because of the high cost and environmental concerns of using herbicides (Lym 1998).

In the northern United States, the brown flea beetle (Aphthona nigriscutis Foudras) and the black flea beetle (Aphthona lacertosa Rosenhauer) have demonstrated considerable and widespread success in reducing leafy spurge (McClay et al. 1995; Kirby et al. 2000; Butler et al. 2006). Prerelease research was conducted regarding possible nontarget effects of Aphthona spp. on North American spurges, including species in the same subgenus (Esula) as leafy spurge. However, the native spurge Euphorbia brachycera Engelm. (formerly Euphorbia robusta), a consubgener, is conspicuously missing from published research involving $A$. nigriscutis and A. lacertosa (e.g.,
Pemberton 1984; Gassmann et al. 1996; Rees et al. 1996). E. brachycera is similar to leafy spurge in its perennial life span and its ecological range; the range of E. brachycera covers the northern Great Plains, from Idaho to Minnesota, and south into Nebraska, New Mexico and Arizona (McGregor 1986; Larson and Johnson 1999; USDA NRCS PLANTS Database 2005, http://plants.usda.gov/).

As a result of the success of flea beetles, their range is expanding to cover a larger part of the range inhabited by $E$. brachycera. This overlap of the target species, the biocontrol agent, and E. brachycera makes E. brachycera a possible candidate for Aphthona spp. feeding and development. While none of the Euphorbia spp. under consideration for protection occurs in areas currently inhabited by leafy spurge and flea beetles, the distribution of E. brachycera is extensive and it could potentially serve as a bridge to threatened Euphorbia species.

The objective of this study was to evaluate the potential impact of introduced flea beetles on E. brachycera. Specifically, the goal was to use ecological similarities and differences among E. brachycera, leafy spurge, and flea beetles to help elucidate any threat to the native, nontarget plant that may be posed by release of these biocontrol agents. A secondary goal was to assess the use of E. brachycera as a food source and developmental host by A. lacertosa in a field setting.

\section{MATERIALS AND METHODS}

Extensive reconnaissance conducted during the 2000 and 2001 field seasons covered the general area included in the research efforts of TEAM Leafy Spurge (The Ecological Area-wide Management of Leafy Spurge [http://www.team.ars.usda.gov]); specifically, selected parts of central Wyoming, western South Dakota and North Dakota, and southeastern Montana. From these areas, 8 study sites were selected based on having populations of E. brachycera greater than 20 individuals within a 1-ha plot and subsequently sampled in June and July 2002. All sites have continental climate, with the majority of precipitation occurring April through September (Young 1981; Ensz 1990).

Four sites were located in the Red Valley of the Black Hills of South Dakota-2 in Wind Cave National Park (Wind Cave NP) (WICA1 and WICA2) and 2 in the Elk Mountains on land managed by the Black Hills National Forest (Black Hills NF) (BH1 and BH2) (Table 1). The sites in Wind Cave NP are typified by mixed grass prairie, dominated by little bluestem 
(Schizachyrium scoparium [Michx.] Nash), western wheatgrass (Pascopyrum smithii [Rydb.] A. Löve), and grama grasses (Bouteloua Lag.) (nomenclature follows NRCS PLANTS Database 2006). The sites on the Black Hills NF are dominated by ponderosa pine (Pinus ponderosa P. \& C. Lawson) with a mixed grass understory, comprised of species similar to those in Wind Cave NP. Soils in the Red Valley are weathered from gypsum and gypsiferous siltstone and are red to reddish-brown in color. The soils are low in fertility and organic matter with low available water capacity, moderate permeability, and medium to rapid runoff (Ensz 1990). Sites were grazed by bison (NP), cattle (NF), and wildlife.

The remaining 4 sites were located near Lander, Wyoming (LAN1, LAN2, LAN3 and LAN4), in south-central Fremont County at the base of the Wind River Range, on private property and land managed by the Bureau of Land Management (BLM). All 4 sites are typified by sagebrush steppe. Dominant species include big sagebrush (Artemisia tridentata [Nutt.] ssp. wyomingensis [Beetle \& Young]) and bluebunch wheatgrass (Pseudoroegneria spicata [Pursh] A. Löve). The 4 study sites are characterized by 2 soil series, Sinkson and Thermopolis (Young 1981). Sinkson soils are well drained and often very deep with moderate permeability. The soil water holding capacity is high, with moderate runoff that results in moderate to highly erodible soils. Thermopolis soils are typically upland soils that are shallow and well-drained, with moderate permeability and low water holding capacity. Sites were grazed by cattle (BLM only) and wildlife.

Once a site was selected, every E. brachycera plant was marked with a pin flag. Because of the low number of plants at each site, it was possible to visually inspect every E. brachycera plant and evaluate it for the presence of flea beetles and insect feeding damage. Evaluation occurred during site reconnaissance in early summer and on the survey date (Table 1). No flea beetles were found on any of the E. brachycera plants.

At each site, a $100 \times 50 \mathrm{~m}$ macroplot was established (except for LAN1, where a $100 \times 100 \mathrm{~m}$ macroplot was used) with the center of each plot placed in the center of the E. brachycera population. Twenty-five $4-\mathrm{m}^{2}$ subplots were randomly placed in each of the 4 quadrants of the macroplot for a total of 100 randomly selected subplots per site. Each subplot was sampled for the presence or absence of E. brachycera, and then subdivided into $41-\mathrm{m}^{2}$ microplots. One microplot was randomly selected per subplot and sampled for foliar cover by species, litter, and bare ground using the following six cover classes: 1) $0 \%-5 \%$, 2) $5 \%-25 \%$, 3) $25 \%-50 \%$, 4) $50 \%-75 \%$, 5) $75 \%-95 \%$, and 6) $95 \%-100 \%$ (Daubenmire 1959). The midpoint value of each cover class was used to calculate mean cover for each microplot. Additionally, varying numbers of subjectively selected $1-\mathrm{m}^{2}$ microplots with E. brachycera present were sampled so that each macroplot had 25 microplots with E. brachycera.

Vegetation analysis involved hierarchical clustering using Euclidean metrics for distance measures, and group linkage followed Ward's method (PC-ORD 1999). The results were used for grouping the microplots with most similar vegetation characteristics, with each site ultimately having 4 groups. After all the microplots were grouped, the microplots within each group were divided into 2 categories: "absent," which contained no E. brachycera plants, and "present," which all contained E. brachycera, regardless of whether the microplot was randomly or subjectively selected. For each site, species of importance were determined by selecting species with a high frequency of occurrence and/or high average percent cover value using dissimilarity analysis (Dyer 1978).

Ten $0.5-\mathrm{kg}$ soil samples $(5$ inside and 5 outside the macroplot) were randomly collected at each site, with the exception of LAN1, where 8 samples (4 inside and 4 outside the macroplot) were collected, and LAN2, where 4 were collected (all within the macroplot). At each location, the surface duff was removed and samples were collected from the top $15 \mathrm{~cm}$ of the soil profile. Each soil sample was analyzed individually at the South Dakota State University Soil Testing Laboratory, Brookings, South Dakota. Samples were analyzed for 30 chemical and physical characteristics.

Soil data were analyzed using principal component analysis (PCA) to evaluate soil characteristics that could potentially be used to predict the presence or absence of E. brachycera. In the course of performing PCA, the number of variables was reduced to a level for which a PCA could be reliably estimated (Hatcher 1994; McCune et al. 2002). The final analysis was performed using the following 11 elements: exchangeable bases of calcium, magnesium and potassium, cation exchange capacity, percentage of exchangeable cations of calcium, magnesium and potassium, saturated paste extracts of calcium and magnesium, saturated paste extract for electrical conductivity (a measure of soil salinity), and gypsum. Since flea beetles are sensitive to soil texture, a separate PCA was conducted using the percent of sand, silt, and clay of the soil samples.

To evaluate the potential use of E. brachycera by flea beetles in a field setting, 2 sites in South Dakota (BH1 and BH2) were selected to serve as beetle release sites. On 17 July 2002, beetles were collected near Ekalaka, Montana (lat $45^{\circ} 53^{\prime} \mathrm{N}$, long $\left.104^{\circ} 23^{\prime} \mathrm{W}\right)$, and approximately $300 \mathrm{~A}$. lacertosa were released on each of 20 (BH1) and 14 (BH2) marked E. brachycera plants. An additional 20 (BH1) and $14(\mathrm{BH} 2)$ E. brachycera plants were located and marked at the opposite end of the macroplot to serve as nonrelease control plants. The low population density of E. brachycera at each site limited the number of plants that could be included in the experiment. We assumed limited dispersal because of the gregarious nature of the insects (McClay et al. 1995) and the wide spacing of E. brachycera plants. LAN1 was considered to have beetles present because the site is immediately adjacent to a population of leafy spurge controlled by flea beetles (A. nigriscutis) released in 1992 by the Fremont County Weed and Pest Department (L. Baker, personal communication, 2003). Additionally, in 1999, beetles and feeding damage were observed on the E. brachycera population at LAN1 (Baker et al. 2004).

Thirty E. brachycera and 30 leafy spurge plants were collected from LAN1 on 17 April 2003. Entire E. brachycera plants, including the tap root and as much of the leafy spurge lateral root system as possible, were collected and placed in plastic containers for transport to a South Dakota State University greenhouse. Mesh insect netting was placed in the bottom of each container to cover drainage holes and over the tops of the containers to contain emerging beetles. Ten and 7 of both release and nonrelease plants were randomly selected and collected on 20 April 2003 from BH1 and BH2, respectively, using the same methods. All plants were kept alive in a 
greenhouse environment until beetle emergence. On 11 June 2003, after full beetle emergence, plants were separated from the soil and inspected for beetle feeding damage and presence of insects. Soil from the leafy spurge plants was sieved through a \#60 sieve to detect beetles in the soil. Biomass samples from all E. brachycera plants collected from BH1, BH2, and LAN1 were retained. Above- and belowground material for each plant was dried separately at $60^{\circ} \mathrm{C}$ for 48 hours and weighed.

A Wilcoxon rank-sum test for 2 samples (Cody and Smith 1997; Zar 1999) was used to test the null hypotheses of no differences $(P>0.05)$ in above- and belowground biomass between release and nonrelease plants (SAS version 8.1, 1999_ 2000). This test was employed because of the small sample size and uneven number of samples. Biomass samples were compared at the site level between release and nonrelease plants using aboveground, belowground, and total (above- and belowground combined) biomass. The CATMOD (CATegorical data MODeling) procedure in SAS (Stokes et al. 2000) was used to test the null hypothesis of no differences in plant mortality between E. brachycera specimens collected and kept in the greenhouse, plants left in the field, plants subjected to beetle releases (release), and those without beetle releases (nonrelease). Each main effect was evaluated, as well as possible interactions between treatments.

\section{RESULTS AND DISCUSSION}

E. brachycera occurred infrequently and in low densities at all sites. WICA1 had the lowest frequency of E. brachycera with $4 \%$ of the random subplots containing plants, while WICA2 had the highest frequency of plants $(19 \%)$. E. brachycera densities ranged from 10 plants $\cdot \mathrm{ha}^{-1}$ at WICA1 to 73 plants $\cdot$ ha $^{-1}$ at LAN2 (data not shown). Concomitantly, foliar cover of E. brachycera was considerably less than $1 \%$ at all sites. Furthermore, the groups created from the cluster analysis revealed that the amount of bare ground served as the largest source of (dis)similarity between vegetation groups and as the primary indicator of E. brachycera presence (Table 2). The 2 plant species that contributed the most to the (dis)similarity at each site are listed in Table 2, along with the foliar cover values for E. brachycera in each group. Plant species serving as dominants varied at each site, suggesting considerable ecological amplitude of E. brachycera with respect to plant associations.

At each of the sites, with the exception of one group at $\mathrm{BH} 2$, the vegetation group with the largest number of subplots with E. brachycera had the highest percentage of bare ground (mean of $51 \%$ for E. brachycera "present" plots; $42 \%$ for "absent" plots). In contrast to the low density observed for E. brachycera, leafy spurge can form dense monotypic stands with stem densities capable of reaching over 350 stems $\cdot \mathrm{m}^{-2}$ (Mundal et al. 2000). Stem density of leafy spurge is often correlated with foliar cover (Butler et al. 2006). Consequently, it is possible for a stand of leafy spurge with high stem density to reach $100 \%$ foliar cover, exposing very little bare ground. The ability of leafy spurge to form dense, monotypic stands is due, in part, to the extensive root system and the ability to form adventitious buds along the entire length of the root (Messersmith et al. 1985). E. brachycera does not have such a root system; rather it forms a single, heavy tap root, with occasional root hairs, from which a single plant arises.

E. brachycera was found to occupy habitats similar to those invaded by leafy spurge. Populations of E. brachycera were found in areas with minor disturbance, e.g., erosive, exposed soils and grazed areas in shrublands (LAN1, LAN2, LAN3, and LAN4) and woodlands (BH1 and BH2), as well as in relatively undisturbed native grasslands (WICA1 and WICA2). Leafy spurge has been documented in the same vegetation types, and occurs with many of the same species that were found at the study sites (Jacobs et al. 2001; Baker et al. 2004; Butler and Cogan 2004; Larson and Grace 2004). Additionally, E. brachycera demonstrated an affinity for coarser textured soils in a fashion similar to leafy spurge (Selleck et al. 1962). Soil texture was quite variable but generally remained consistent within sites. Although the 72 soil samples fell into 7 texture classes, soils at sites were predominately moderately fine to medium textured (Table 3). Seventy-one percent of the $E$. brachycera population occupied medium to moderately coarse textured soils while $29 \%$ occurred in moderately fine textured soil. In the PCA of the soil chemistry, axis 1 explained 95\% of the variation, while axis 2 explained $2 \%$. The sites were differentiated along a gradient of macronutrients dominated by the presence of calcium. However, the PCA revealed no distinction between soil samples taken from within the $E$. brachycera population and those from outside the population.

While both leafy spurge and E. brachycera occupy a wide variety of habitats, flea beetles have a more restricted ecological tolerance. In their native habitat, Nowierski et al. (2002) reported $A$. lacertosa to be more common on finer textured, mesic to hydric soils while A. nigriscutis dominated coarser, drier soils. Lym (1998) and Jacobs et al. (2001) found that introduced populations of A. nigriscutis in the United States did not establish on sites with greater than $80 \%$ sand. Lym (1998) reported similar results for A. lacertosa. Parker (2002) released flea beetles ( $A$. lacertosa and A. nigriscutis) in Montana and South Dakota. On release sites where soil texture was documented, the average sand content was 52\% (range 19\%-85\%). By 2003, A. lacertosa establishment was successful on all but one site, along the Moreau River floodplain with mesic soils in South Dakota, while A. nigriscutis were infrequent constituents on all sites (Murphy 2004). In the present study, soil texture fell within the range found to be acceptable for beetles; thus, soil is not considered to be a factor in preventing establishment of beetles in E. brachycera habitats.

In addition to soil requirements, flea beetles require the extensive leafy spurge root system to complete their life cycle, as it serves as a food source during the larval stage (Hansen et al. 1997). The difference in root systems is likely the most significant difference between E. brachycera and leafy spurge, particularly in terms of the ability of flea beetles to successfully complete a life cycle. Additionally, flea beetles are gregarious in nature and the dense stands of leafy spurge provide enough food for flea beetles to perpetuate, whereas the sparseness of E. brachycera would likely not be able to support a population of flea beetles through multiple life cycles.

The secondary objective of this study was to evaluate the potential use of E. brachycera by biocontrol agents in a field setting. This was meant to serve as a nochoice feeding trial in the environment in which E. brachycera naturally occurred. Large 
Table 2. Mean percent foliar cover $( \pm S D)$ for species of importance and their contribution to (dis)similarity for each study site. Percent foliar cover is mean of all microplots in each group separated into Euphorbia brachycera absent and present.

\begin{tabular}{|c|c|c|c|c|c|c|c|c|c|}
\hline & \multirow{3}{*}{$\begin{array}{l}\text { Contribution to } \\
\text { (dis)similarity (\%) }\end{array}$} & \multicolumn{2}{|c|}{ Group 1} & \multicolumn{2}{|c|}{ Group 2} & \multicolumn{2}{|c|}{ Group 3} & \multicolumn{2}{|c|}{ Group 4} \\
\hline & & \multicolumn{2}{|c|}{ E. brachycera } & \multicolumn{2}{|c|}{ E. brachycera } & \multicolumn{2}{|c|}{ E. brachycera } & \multicolumn{2}{|c|}{ E. brachycera } \\
\hline & & absent & present & absent & present & absent & present & absent & present \\
\hline Wind Cave 1 & - & $n^{1}=32$ & $n=14$ & $n=19$ & $n=7$ & $n=24$ & $n=3$ & $n=20$ & $n=2$ \\
\hline Bare ground & 32 & 49.4 (16.2) & $50.3(15.9)$ & $7.3(6.4)$ & $21.9(11.0)$ & $9.0(6.6)$ & $15.5(0)$ & $3.6(4.2)$ & $15.5(0)$ \\
\hline Little bluestem & 17 & $27.9(14.9)$ & $16.8(15.3)$ & $31.4(14.5)$ & $33.0(13.4)$ & $43.2(10.4)$ & $47.1(27.4)$ & $17.1(13.7)$ & $7.8(11.0)$ \\
\hline Big bluestem & 9 & $2.4(5.1)$ & $2.8(5.5)$ & $16.3(22.6)$ & $22.9(15.1)$ & $7.8(7.9)$ & $5.2(8.9)$ & $\mathrm{T}$ & - \\
\hline E. brachycera & 1 & - & $2.3(0.7)$ & - & $2.5(0)$ & - & $2.5(0)$ & - & $2.5(0)$ \\
\hline Wind Cave 2 & - & $n=20$ & $n=18$ & $n=33$ & $n=4$ & $n=13$ & $n=2$ & $n=21$ & $n=0$ \\
\hline Bare ground & 39 & $55.1(17.6)$ & $55.6(18.1)$ & $8.8(6.6)$ & $5.8(6.5)$ & $9.5(6.7)$ & $9.0(9.2)$ & $6.8(6.2)$ & - \\
\hline Little bluestem & 30 & $22.6(13.7)$ & 17.5 (12.6) & $34.9(8.8)$ & $38.0(0)$ & $13.8(9.7)$ & $9.0(9.2)$ & $70.5(10.9)$ & - \\
\hline Big bluestem & 8 & $2.3(8.5)$ & $1.0(3.7)$ & $8.8(18.1)$ & $3.9(7.8)$ & $3.8(6.7)$ & - & $1.1(3.4)$ & - \\
\hline E. brachycera & 4 & - & $4.0(4.2)$ & - & $5.8(6.5)$ & - & $2.5(0)$ & - & - \\
\hline Black Hills 1 & - & $n=43$ & $n=16$ & $n=26$ & $n=8$ & $n=13$ & $n=5$ & $n=12$ & $n=0$ \\
\hline Bare ground & 51 & $84.1(12.7)$ & $81.1(12.8)$ & $58.4(13.5)$ & $63.0(0)$ & $23.2(12.7)$ & $33.5(10.0)$ & $11.2(6.4)$ & - \\
\hline Little bluestem & 10 & $11.8(15.6)$ & $16.3(14.6)$ & $4.3(7.0)$ & $7.6(8.3)$ & $10.7(11.0)$ & $9.8(7.9)$ & $3.0(5.9)$ & - \\
\hline Threadleaf sedge & 8 & $2.3(5.0)$ & $2.1(5.3)$ & $3.5(6.1)$ & $6.4(7.6)$ & $12.0(10.2)$ & $12.4(6.9)$ & $32.4(10.2)$ & - \\
\hline E. brachycera & 2 & - & $3.3(3.3)$ & - & $2.5(0)$ & - & $2.5(0)$ & - & - \\
\hline Black Hills 2 & - & $n=26$ & $n=12$ & $n=30$ & $n=6$ & $n=19$ & $n=2$ & $n=23$ & $n=0$ \\
\hline Bare ground & 34 & $48.6(12.6)$ & $63.0(0)$ & $87.1(4.3)$ & $85.5(0)$ & $22.7(16.8)$ & 50.5 (17.7) & $15.3(13.6)$ & - \\
\hline Blue grama & 15 & $5.1(7.1)$ & $1.5(4.5)$ & $\mathrm{T}$ & - & $50.9(16.8)$ & $38.0(0)$ & $5.2(7.1)$ & - \\
\hline Ponderosa pine ${ }^{2}$ & 8 & $\mathrm{~T}$ & $3.6(10.9)$ & $\mathrm{T}$ & - & $3.3(14.5)$ & - & $12.4(30.9)$ & - \\
\hline E. brachycera & 3 & - & $4.7(5.1)$ & - & $6.8(6.7)$ & - & $2.5(0)$ & - & - \\
\hline Lander 1 & - & $n=6$ & $n=12$ & $n=12$ & $n=9$ & $n=34$ & $n=8$ & $n=37$ & $n=2$ \\
\hline Bare ground & 27 & $38.0(0)$ & $38.0(0)$ & $38.0(0)$ & $38.0(0)$ & $26.4(23.8)$ & $51.1(22.0)$ & $16.1(13.9)$ & $15.5(0)$ \\
\hline Antelope bitterbrush & 12 & - & - & - & - & $\mathrm{T}$ & - & $12.4(19.5)$ & $7.8(11.0)$ \\
\hline Skunkbrush & 12 & - & - & - & - & - & - & $6.7(21.8)$ & - \\
\hline E. brachycera & 1 & - & $2.5(0)$ & - & $2.5(0)$ & - & $2.5(0)$ & - & $2.5(0)$ \\
\hline Lander 2 & - & $n=22$ & $n=15$ & $n=46$ & $n=10$ & $n=4$ & $n=7$ & $n=20$ & $n=1$ \\
\hline Bare ground & 40 & $87.8(4.9)$ & $86.3(3.2)$ & $59.4(19.0)$ & $67.5(9.5)$ & $85.5(0)$ & $85.5(0)$ & $85.5(0)$ & 85.5 \\
\hline Big sagebrush & 23 & $\mathrm{~T}$ & $\mathrm{~T}$ & $17.6(17.3)$ & $5.2(7.2)$ & $\mathrm{T}$ & - & $1.1(1.3)$ & - \\
\hline Threadleaf sedge & 6 & $\mathrm{~T}$ & $\mathrm{~T}$ & $5.4(9.4)$ & $4.1(6.1)$ & $\mathrm{T}$ & $\mathrm{T}$ & $3.5(6.2)$ & 2.5 \\
\hline E. brachycera & 2 & - & $2.5(0)$ & - & $2.5(0)$ & - & $2.5(0)$ & - & 2.5 \\
\hline Lander 3 & - & $n=22$ & $n=26$ & $n=25$ & $n=3$ & $n=27$ & $n=1$ & $n=21$ & $n=0$ \\
\hline Bare ground & 45 & $77.0(16.9)$ & $75.6(12.1)$ & $72.0(11.3)$ & $63.0(0)$ & $34.7(8.1)$ & 38.0 & $34.8(24.8)$ & - \\
\hline Antelope bitterbrush & 18 & - & - & $\mathrm{T}$ & - & $1.7(5.0)$ & - & $30.1(25.9)$ & - \\
\hline Big sagebrush & 16 & $1.6(3.3)$ & $\mathrm{T}$ & $12.6(8.2)$ & $11.2(7.5)$ & $24.1(14.5)$ & - & $26.4(14.4)$ & - \\
\hline E. brachycera & 1 & - & $2.5(0)$ & - & $2.5(0)$ & - & $2.5(0)$ & - & - \\
\hline Lander 4 & - & $n=42$ & $n=17$ & $n=25$ & $n=7$ & $n=14$ & $n=4$ & $n=16$ & $n=0$ \\
\hline Bare ground & 46 & $74.0(29.0)$ & $85.5(0)$ & $35.9(25.6)$ & $59.4(9.4)$ & $38.0(0)$ & $38.0(0)$ & $41.6(17.2)$ & - \\
\hline Antelope bitterbrush & 24 & $13.7(29.1)$ & - & $24.0(17.9)$ & $7.6(14.6)$ & $5.5(7.7)$ & $3.9(7.8)$ & $6.8(7.9)$ & - \\
\hline Big sagebrush & 12 & $12.0(10.8)$ & $1.0(1.3)$ & $12.2(12.1)$ & $2.9(5.7)$ & $11.3(7.0)$ & $8.4(8.3)$ & $41.0(11.9)$ & - \\
\hline E. brachycera & 2 & - & $3.3(4.4)$ & - & $2.5(0)$ & - & $2.5(0)$ & - & - \\
\hline
\end{tabular}

${ }^{1} n$ indicates number of microplots; $T$, trace; and -, species is absent.

${ }^{2}$ Includes Ponderosa pine saplings and trees up to $3 \mathrm{~m}$ in height; excludes overstory trees.

populations of E. brachycera simply did not exist at sites also inhabited by leafy spurge, so there were limits to what could be used as controls. From all 3 sites with flea beetles present, a total of 94 plants were collected and used in the greenhouse experiment that included 64 E. brachycera plants and 30 leafy spurge plants. Four beetles, 3 A. lacertosa, and 1 A. nigriscutis emerged from the leafy spurge plants collected from LAN1.

One site in LAN1 was adjacent to a stand of leafy spurge that had been successfully reduced by a population of $A$. nigriscutis released by the Fremont County Weed and Pest 
Table 3. Percentage of soil samples in each soil texture class occurring at the study sites and percent of soil samples taken from each soil texture class inside and outside of the Euphorbia brachycera populations. Texture system based on United States Department of Agriculture Classification System. ${ }^{1}$

\begin{tabular}{|c|c|c|c|c|c|c|}
\hline \multirow[b]{2}{*}{ Soil texture } & \multirow{2}{*}{$\begin{array}{c}\text { Textural } \\
\text { class }\end{array}$} & \multirow{2}{*}{$\begin{array}{l}\text { Wind Cave } \\
\text { sites 1-2 } \\
n=20\end{array}$} & \multirow{2}{*}{$\begin{array}{l}\text { Black Hills } \\
\text { sites 1-2 } \\
n=20\end{array}$} & \multirow{2}{*}{$\begin{array}{l}\text { Lander } \\
\text { sites 1-4 } \\
n=32\end{array}$} & \multirow[t]{2}{*}{$\begin{array}{c}\text { Inside } \\
\text { E. brachycera } \\
\text { population }\end{array}$} & \multirow[t]{2}{*}{$\begin{array}{l}\text { Outside } \\
\text { E. brachycera } \\
\text { population }\end{array}$} \\
\hline & & & & & & \\
\hline Clay & fine & - & - & $3 \%$ & - & $3 \%$ \\
\hline Clay loam & moderately fine & $40 \%$ & $15 \%$ & $28 \%$ & $26 \%$ & $29 \%$ \\
\hline Silty clay loam & moderately fine & $30 \%$ & - & - & - & $18 \%$ \\
\hline Sandy clay loam & moderately fine & - & - & $6 \%$ & $3 \%$ & $3 \%$ \\
\hline Silt loam & medium & $10 \%$ & $75 \%$ & $3 \%$ & $34 \%$ & $15 \%$ \\
\hline Loam & medium & $20 \%$ & $10 \%$ & $53 \%$ & $34 \%$ & $29 \%$ \\
\hline Sandy loam & moderately coarse & - & - & $6 \%$ & $3 \%$ & $3 \%$ \\
\hline
\end{tabular}

${ }^{1} n$ indicates number of soil samples; - , soil texture is absent.

Department (L. Baker, personal communication, 2003). Leafy spurge was declining on this site as a result of beetles, and therefore was considered to be a site known to be able to support an established beetle population. The few beetles that emerged from the leafy spurge samples indicated beetles were still present at the site and, under conditions of declining leafy spurge, may have needed alternative hosts. Baker et al. (2004) described E. brachycera mortality and adult feeding damage in years when leafy spurge was more abundant; however, they were unable to confirm beetle use as the cause of E. brachycera mortality. Although there was adult feeding damage on $E$. brachycera by $A$. nigriscutis, the damage was not severe enough to reduce the E. brachycera population. Indeed, the number of E. brachycera plants recorded at the site increased from 31 to 542 (on a 1.5-ha site) during the 3 -year evaluation period of the study (Baker et al. 2004). In the present study, conducted during the growing seasons following Baker et al. (2004), there was no observed feeding damage to E. brachycera, nor did any beetles emerge from the collected E. brachycera plants.

On sites where beetles were released (BH1 and $\mathrm{BH} 2)$, no insects emerged from any of the collected E. brachycera plants, nor was there any observed feeding damage on plants at either of the sites. There were no differences $(P>0.05)$ in plant mortality between collected plants and those left in the field, nor between release and nonrelease plants. From all the E. brachycera plants collected, the above- and belowground biomass measurements were similar for release and nonrelease plants $(P>0.05$ for all tests). The end result was that none of the E. brachycera populations were adversely impacted by the presence of flea beetles.

\section{MANAGEMENT IMPLICATIONS}

The close taxonomic and geographic relationship between leafy spurge and E. brachycera increases the opportunity for biocontrol agents to find the native, nontarget spurge an acceptable host. Prerelease laboratory tests indicated that flea beetles have a narrow host breadth; however, not every aspect of the natural environment can be mimicked. The approach of this study was to use the ecological characteristics of two taxonomically related plants to assess the potential impact of biological control agents on a nontarget species.
Populations of E. brachycera occupied sites with soils and resident vegetation similar to sites invaded by leafy spurge. Unlike leafy spurge, E. brachycera occurs infrequently and in low densities, and did not form monotypic stands due to differences in root structure. These are fundamental differences with respect to the flea beetles' requirements to complete a life cycle. Additionally, releasing beetles on E. brachycera plants at locations where no leafy spurge was present created a fieldbased nochoice feeding trial. Lack of establishment of beetles and no evidence of an adverse impact on selected plants suggests that E. brachycera may be an unacceptable source of food and a poor substitute for larval development.

We know of no other studies that employed the use of ecological differences to evaluate the potential for nontarget impacts. This study provided information beyond whether flea beetles would consume or lay eggs on species taxonomically related to the target. It additionally assessed the likelihood of host-shifting by evaluating the functional differences among biocontrol agent, its intended target, and a potential nontarget species. When used in conjunction with laboratory tests, an analysis of the ecological separation of target and nontarget species will help provide a more complete evaluation of possible biocontrol agents prior to release.

\section{ACKNOWLEDGMENTS}

Authors wish to thank Gary Larson, Rudy King, Lars Baker, Nancy Webber, Shauna Marquardt, Chad Prosser, and the staff at Wind Cave National Park for their valuable assistance during this study. We also thank Gerry Anderson, Dean Pearson, and all the reviewers of this manuscript.

\section{LITERATURE CITED}

Baker, J. L., N. A. P. Webber, and K. K. Johnson. 2004. Non-target impacts of Aphthona nigriscutis, a biocontrol agent for Euphorbia esula (leafy spurge), on a native plant Euphorbia robusta. In: J. M. Cullen, D. T. Briese, D. J. Kriticos, W. M. Lonsdale, L. Morin, and J. K. Scott [EDs.]. Proceedings of the XI International Symposium on the Biological Control for Weeds; 27 April-2 May 2003; Canberra, Australia: Commonwealth Scientific and Industrial Research Organisation Entomology. p. 247-251.

Bangsund, D. A., and F. L. Leistritz. 1991. Economic impact of leafy spurge in Montana, South Dakota and Wyoming. Fargo, ND: North Dakota State 
University, North Dakota Agricultural Experiment Station, NDSU Agricultural Economics Report No 275. 105 p.

Butler, J. L., AND D. R. Cogan. 2004. Leafy spurge effects on patterns of plant species richness. Journal of Range Management 57:305-311.

Butler, J. L., M. S. Parker, and J. T. Murphy. 2006. Efficacy of flea beetle control of leafy spurge in Montana and South Dakota. Rangeland Ecology and Management 59:453-461.

Cody, R. P., AND J. K. Smith. 1997. Applied statistics and the SAS ${ }^{\circledR}$ programming language. 4th ed. Upper Saddle Creek, NJ: Prentice Hall. p. 138-149.

DaubenmiRe, R. 1959. A canopy-coverage method of vegetation analysis. Northwest Science 33:43-64.

DYER, D. P. 1978. An analysis of dissimilarity using multiple environmental variables. Ecology 59:117-125.

Ensz, E. H. 1990. Soil survey of Custer and Pennington Counties, Black Hills Parts, South Dakota. United States Department of Agriculture: Soil Conservation Service and Forest Service. $295 p$.

Gassmann, A., D. Schroeder, E. Maw, and G. Sommer. 1996. Biology, ecology, and host specificity of European Aphthona spp. (Coleoptera, Chrysomelidae) used as biocontrol agents for leafy spurge Euphorbia esula (Euphorbiaceae) in North America. Biological Control 6:105-113.

Hansen, R. W., R. D. Richard, P. E. Parker, and L. E. Wendel. 1997. Distribution of biological control agents of leafy spurge (Euphorbia esula L.) in the United States: 1988-1996. Biological Control 10:129-142.

HATCHER, L. 1994. A step-by-step approach to using the SAS system for factor analysis and structural equation modeling. Cary, NC: SAS Institute Inc. $588 \mathrm{p}$.

Jacobs, J. S., R. L. Sheley, N. R. Spencer, and G. Anderson. 2001. Relationships among edaphic, climatic, and vegetation conditions at release sites and Aphthona nigriscutis population density. Biological Control 22:46-50.

Kirby, D. R., R. B. Carlson, K. D. Krabbenhoft, D. Mundal, and M. M. Kirby. 2000. Biological control of leafy spurge with introduced flea beetles (Aphthona spp.). Journal of Range Management 53:305-308.

LaRSon, D. L. And J. B. Grace. 2004. Temporal dynamics of leafy spurge (Euphorbia esula) and two species of flea beetles (Aphthona spp.) used as biological control agents. Biological Control 29:207-214.

Larson, G. E. And J. R. Johnson. 1999. Plants of the Black Hills and Bear Lodge Mountains. Brookings, SD: South Dakota State University, College of Agriculture and Biological Sciences, South Dakota Agricultural Experiment Station. 608 p.

Louda, S. M., A. E. Arnett, T. A. Rand, and F. L. Russell. 2003. Invasiveness of some biological control insects and adequacy of their ecological risk assessment and regulation. Conservation Biology 17:73-82.

Louda, S. M., D. Kendall, J. Connor, and D. Simberloff. 1997. Ecological effects of an insect introduced for the biological control of weeds. Science 277: 1088-1090.

LOUDA, S. M., AND C. W. O'Brien. 2002. Unexpected ecological effects of distributing the exotic weevil, Larinus planus (F.) for the biological control of Canada thistle. Conservation Biology 16:717-727.

LYM, R. G. 1998. The biology and integrated management of leafy spurge (Euphorbia esula) on North Dakota rangeland. Weed Technology 12:367-373.

McClay, A. S., D. E. Cole, P. Harris, and C. J. Richardson. 1995. Biological control of leafy spurge in Alberta: Progress and prospects. Vegreville, Alberta, Canada: Alberta Environmental Centre Vegreville. ABVC 95-R2. 44 p.

McCune, B., J. B. Grace, and D. L. Urban. 2002. Analysis of ecological communities. Gleneden Beach, OR: MJM Software Design. 300 p.

McGregoR, R. L. 1986. Euphorbiaceae. In: Great Plains Flora Association [ed.]. Flora of the Great Plains. Lawrence, KS: University of Kansas. p. 535-553.

Messersmith, C. G., R. G. Lym, and D. S. Galitz. 1985. Biology of leafy spurge. In: A. K. Watson [ED.] Leafy spurge, monograph series no 3. Champaign, IL: Weed Science Society of America. p. 42-55.

Mundal, D. A., D. L. Olson, and R. B. Carlson. 2000. The effect of Aphthona spp. flea beetle (Coleoptera: Chrysomelidae) larval feeding on leafy spurge, Euphorbia esula L., root systems and stem density in North Dakota: 198696. From B. Redlin [ED.]. Purge Spurge: Leafy Spurge Database. Version 4.0.
Sidney, MT: United States Department of Agriculture Agricultural Research Service. Available at: http://www.lib.ndsu.nodak.edu/research/subjects/ag/ spurge_wl/spurge/pdffiles/biocontrl/insect/1892mu00.pdf. Accessed 21 March 2006.

Murphy, J. T. 2004. Assessing area-wide biological control of leafy spurge in Montana and South Dakota [MS thesis]. Brookings, SD: South Dakota State University. $93 p$.

Nowierski, R. M., Z. Zeng, D. Schroeder, A. Gassmann, B. C. Fitzgerald, and M. Cristofaro. 2002. Habitat associations of Euphorbia and Aphthona species from Europe: development of predictive models for natural enemy release with ordination analysis. Biological Control 23:1-17.

PARKeR, M. S. 2002. Assessing biological control agents for area-wide control of leafy spurge with foci in Montana and South Dakota [MS thesis]. Warrensburg, M0: Central Missouri State University. 109 p.

PC-ORD: Multivariate analysis OF ECOLOGICAL data [computer program]. 1999. Version 4. Gleneden Beach, OR: MJM Software Design.

Pearson, D. E., and R. M. Callaway. 2003. Indirect effects of host-specific biological control agents. Trends in Ecology and Evolution 18:456-461.

Pemberton, R. W. 1984. Native plant considerations in the biological control of leafy spurge. In: E. S. Delfosse [ED.]. Proceedings of the VI International Symposium for the Biological Control of Weeds; 19-25 August 1984; Vancouver, Canada: Agriculture Canada. p. 365-390.

Pemberton, R. W. 1995. Cactoblastis cactorum (Lepidoptera: Pyralidae) in the United States: an immigrant biological control agent or introduction of the nursery industry? American Entomologist 41:230-232.

Pemberton, R. W. 2000. Predictable risk to native plants in weed biological control. Oecologia 125:489-494.

Rees, N. E., R. W. Pemberton, N. R. Spencer, P. C. Quimby, JR., and R. M. Nowierski. 1996. Section II: Weeds and approved biological control agents-the spurges. In: N. E. Rees, R. W. Pemberton, N. R. Spencer, P. C. Quimby, Jr., and R. M. Nowierski [EDS.]. Biological control of weeds in the West. Bozeman, MT: Western Society of Weed Science. $29 \mathrm{p}$.

SAS VERSION 8.1 FOR WINDOWS [computer program]. 1999-2000. Cary, NC: SAS Institute Inc.

Selleck, G. W., R. T. Coupland, and C. Frankton. 1962. Leafy spurge in Saskatchewan. Ecological Monographs 32:1-29.

Simberloff, D., And P. Stiling. 1996. How risky is biological control? Ecology 77 : 1965-1974.

StILING, P., AND D. C. Moon. 2001. Protecting rare Florida cacti from attack by the exotic cactus moth, Cactoblastis cactorum (Lepidoptera: Pyralidae). Florida Entomologist 84:506-509.

Stokes, M. E., C. S. Davis, AND G. G. Koch. 2000. Categorical data analysis using the SAS system. 2nd ed. Cary, NC: SAS Institute Inc. 626 p.

TEAM LeAFY SPURGE. 2002-2006. Available at http://www.team.ars.usda.gov/. Accessed March 2006.

Turner, C. E., R. W. Pemberton, and S. S. Rosenthal. 1987. Host utilization of native Cirsium thistles (Asteraceae) by introduced weevil Rhinocyllus conicus (Coleoptera: Curculionidae) in California. Environmental Entomology 16: 111-115.

United States Department of Agriculture Natural Resources Conservation Service. 2006. The PLANTS Database. Version 3.5. Available at http://plants.usda.gov. Data compiled from various sources by M. W. Skinner. Baton Rouge, LA: National Plant Data Center.

Van Driesche, R. G. 1994. Classical biological control of environmental pests. Florida Entomologist 77:20-33.

Young, J. F. 1981. Soil survey of Fremont County, Wyoming, Lander Area. United States Department of Agriculture Soil Conservation Service in cooperation with University of Wyoming Agricultural Experiment Station. $127 \mathrm{p}$.

Zar, J. H. 1999. Biostatistical Analysis. 4th ed. Upper Saddle River, NJ: Prentice Hall. $663 p$.

ZwölfeR, H., AND P. HARRIS. 1984. Biology and host specificity of Rhinocyllus conicus (Froel.) (Col., Curculionidae), a successful agent for the biocontrol of the thistle, Carduus nutans L. Journal of Applied Entomology 97:36-62. 